\title{
INTRODUCCIÓN: ANTONIO GAMONEDA O LA PALABRA DAÑADA
}

\author{
Rafael MORALES BARBA \\ Universidad Autónoma de Madrid
}

Con esa equivalencia propusimos la poética del poeta leonés frente a otras disyunciones. El otro posible marbete para el Congreso que celebramos en el año 2009 en la Universidad Autónoma de Madrid estaba ocupado. Lo había planteado ajustada y previamente Fernando Rodríguez de la Flor: «Antonio Gamoneda y la poética del subdesarrollo español», parafraseando una propuesta de referencia de Vicenç Navarro, El subdesarrollo social de España. Es decir, la época de la vivencia del poeta ovetense de origen, leonés de corazón. Nosotros, sin/embargo, preferimos anteponer lo primordial en un escritor, la palabra poética, asumiendo en ella la callada insurgencia de los desheredados. Hemos cambiado solamente el orden.

Antonio Gamoneda o la palabra dañada y conmocionada de la víctima, de un escritor de blues y salmos estremecedores publicados tardíamente pues, como es sabido, la mayor parte de su obra ve luz con el final del franquismo y, fundamentalmente, con la democracia. Una retaguardia a causa de la herida, pero con una poética llena de compromiso. Se convierte así más que en un rebelde desde el poema en un testigo del daño en una época atenta ya a otros espacios. Frente al mercado de las editoriales girando sobre el exceso de mito del poeta adolescente, Antonio Gamoneda proponía con la fortaleza de los luchadores el buen hacer del artista maduro. Previamente había visto luz Sublevación inmóvil, en 1960, y además en el siempre actual Adonáis (traductor inicial de Wallace Stevens), pues hay que evitar tópicos. Pero la eclosión del poeta como tal es tardía y con muchas deudas con cuanto venía le había conformado (desde Dámaso Alonso y Blas de Otero) hasta cuanto le iba llegando desde las poéticas del silencio. Y fundamentalmente desde el lenguaje propuesto por uno de los poetas e intelectuales de mejor hacer y mayor personalidad desde las poéticas de la expectación y la desilusión de ser, como fue (y es) un inquietante propositor del moderno nihilismo y quietismo en español, José Ángel Valente. Y no solo. Antonio Gamoneda se nos presenta desde esa perspectiva como un escritor comprometido desde la búsqueda de un lenguaje tanto como desde el daño y la denuncia de cuanto no pudo decir, o no supo, en su momento. Y por esa trocha camina hacia un enternecido compromiso con los desheredados y perseguidos, sin pausa y sin pacto, casi secretamente, como fiel testigo del horror. 
De una tragedia donde conviven la orfandad vital conmocionada y la necesidad de no callar las conmociones de otros, junto a la tarea del aprendizaje para lograr voz desde su Bildungsroman lírico.

La poesía de Antonio Gamoneda se propone desde esa perspectiva sin pequeñas causas, sino con todo lo contrario, con causas mayores. Fundamentalmente con la del escritor comprometido desde la violencia sentida como propia y lanzada e implicada en el dolor ajeno como razón del canto. De quien siente su dolor y el de otros como un animal de fondo, por decirlo con Juan Ramón, como un poeta de fondo que lanza la red al fondo, entre Paul Celan y la experiencia abisal propuesta por el último José Ángel Valente, pero sin tener el suelo como cielo, ni a andar cabeza abajo, por decirlo con el poeta búlgaro-alemán. Gamoneda no es vencido finalmente por lo matérico o por el horror vacui, y vence desde su sensibilidad con el oprimido, pues no se doblega hacia el vacío o sus narcisismos que a veces le cantan mientras permanece amarrado al mástil. Por eso le homenajeamos. Y por su vértigo de palabras intensificando la conciencia hasta lo insoportable, lacerantes, conjurando el dolor mediante la escritura. Se nos mostraba así como un complejo sujeto hijo de la humildad aprendiendo el oficio y el talento abocado a una perspectiva casi unívoca desde la inventio. Fértil en el poema en prosa, el proema, por decirlo con Francis Ponge más que con Octavio Paz, sin lanzarotismo (que no es un término descalificador como algunos creen, sino descriptor, del jabesianismo calcinado del ser, visto por el isleño Sánchez Robayna. Autor de un buen libro, Tinta, desde esa perspectiva, además). Las Lápidas de Antonio Gamoneda hablaban sin embargo de los extrarradios y del otro, no eran omphálicas, sino experienciales, con una poética de la experiencia diferente a la más conocida. Una que se proponía desde el existencialismo desgarrado y el exceso de conocimiento hacia la disolución, hacia el no saber y el apartamiento de tanta realidad insoportable, pues la herida pesaba excesivamente. Pero no sin haberla conjurado (mostrado) antes, tras sufrir el horror y su hiperestesia, que es voz que está dejando de estar de moda. Casi tanto como la poesía comprometida, o la misma de circunstancias, pues vivimos bajo lo desolado, metapoético, lo irónico y lo ensimismado, con mucha sospecha y confidencia, poca insurgencia como marca.

Una generación desarraigada desaparecerá con él. Ya se han ido sus mayores y muchos de sus contemporáneos y queridos José Ángel Valente o Claudio Rodríguez, o los no tan admirados o mal comprendidos (como fue él para ellos incomprendido). Y pienso a la carrera en el buen Ángel González o en promociones ajenas a lo sálmico o el enigma en su ruta hacia la naturalidad del decir. También toda una tropología de tristes haces de huesos castigados, que hacen de su poesía vallejiana insurgencia y piedad enferma, desaparecerán tras haber cantado desde el horror o el silencio. Quedarán sus versos sin pequeñas causas como testimonio. Con esa impronta y esa perspectiva del poeta asumiendo como nadie un momento de nuestra reciente historia. Una historia que le marca y aísla, e incluso impide comprender lo ajeno a su época y perímetro lírico, pues el daño ha sido grande y cada sujeto tiene su historia, perspectiva e idiolecto como leño salvador. Un triunfo de la perseverancia y talento de una obra en marcha celebramos esos días en definitiva. La del artista inscrito en la poesía como pensamiento. Aunque realmente en Antonio Gamoneda prime siempre la poesía como sentimiento y, sobre todo, la misericordia y la solidaridad como un valor posible en la sociedad contemporánea, que 
le han llevado a cuestionar el sentido conferido a esa voz (misericordia) por María Zambrano frente a la clemencia. Un sentimiento siempre frente a pensamiento, entendiéndolo a la manera del pensar poético planteado, por ejemplo, por Rainer María Rilke, pues otra ha sido su dura y extrema circunstancia.

Durante los días 15, 16 y 17 de abril de 2009, se celebró este homenaje en la Universidad Autónoma de Madrid y con la jornada de clausura en la Biblioteca Nacional. Previamente, el día 14, inauguramos los festejos líricos, pero muy rigurosos y académicos, como podrá el lector comprobar en las sesudas páginas que siguen, en la Tertulia Literaria Hispanoamericana de Rafael Montesinos, decana de los encuentros y recitales poéticos con lugar todavía en el Colegio Mayor Guadalupe. Fueron pues cuatro días extenuantes, casi tanto como los preparativos junto al comité científico formado por Xelo Candel, María Jesús Zamora Calvo y Carlota Fernández-Jáuregui Rojas, y todos los estudiantes que colaboraron también desinteresadamente. Cuatro días imposibles sin tantas ayudas como tuvimos y difícilmente resumibles en su extensión. Indudablemente gracias a la Facultad de Filosofía y Letras, y al Departamento de Filología Española de la Universidad Autónoma de Madrid, y cuya ayuda fue uno de los pilares del evento. Muy especialmente debemos citar al Vicerrectorado de Extensión Universitaria, y a quien era su auriga entonces, Pedro Martínez Lillo, ferviente defensor durante muchos años de cuantas aventuras líricas emprendíamos tal y como hace ahora Valeria Camporesi. También hay que agradecer muchas cosas muy diferentes a Tomás Albaladejo y a José Manuel Cuesta Abad. Suya fue la lección inaugural de un curso con más de cien asistentes por sesión. Y hasta el último día, donde Antonio García Berrio, impartió la conferencia de clausura. Muchas gracias igualmente a Saint Louis University y a quien comandaba la cuestión literaria, Ángeles Encinar. A su generosidad, ahínco y paciencia para poder hacer realidad nuestros deseos debemos mucho.

No debe faltar de ninguna de las maneras la Dirección General del Libro, Archivos y Bibliotecas. Y mucho menos Rogelio Blanco, que desde hace mucho tiempo ayuda a diversas empresas líricas, como esta, con una generosidad y amistad con la poesía extrañas en nuestra sociedad de opulentos. Esta doncella menesterosa, en palabras de Cervantes, necesita y vive de esos apoyos constructores de ciudadanos en una sensibilidad y un mundo posible y mejor. «Poesía y Divergencia», curso continuador del pionero de Joaquín Benito de Lucas (Reflexiones sobre mi poesía), desde 1980 y en la UAM, ha sido el marco edificador de este Congreso que sin la ayuda de la Dirección General del Libro no habría tenido lugar. Muchas gracias por todo ese esfuerzo y a la extinta Sociedad Estatal de Conmemoraciones Culturales también por el soporte económico y de medios con que sostuvieron los pilares que nosotros no podíamos cimentar bien. Especialmente a Elena Díaz Gómez-Zorrilla, cuyo apoyo y simpatía fueron imprescindibles. 